\title{
Genetic Differentiation of Archachatina marginata Populations from Three Vegetation Zones Using Radom Amplified Polymorphic DNA Polymerase Chain Reaction
}

\author{
Comfort O. AFOLAYAN, Michael O. AWODIRAN*
}

Obafemi Awolowo University, Faculty of Science, Department ofZoology, P.M.B.13OAU, Ile-Ife, Nigeria; michfermi@yahoo.com ("correspondingauthor)

\begin{abstract}
The genetic differentiation of Archachatina marginata populations from three different zones of Nigeria was studied with a view to delimiting them into sub-species. One hundred and nineteen (119) snail specimens were collected, comprising of forty (40) specimens from Yenagoa (Mangrove forest) and from Kabba (Guinea Savanna) and thirty nine (39) specimens were from Ile-Ife (Rainforest). Eight parameters of the shell specimens of $A$. marginata which included height of shell, width of shell, aperture height, aperture width, spire length, spire width, penultimate whorl length and first whorl length were subjected to Principal Component Analysis (PCA) and Canonical Variates Analysis (CVA) to delimit the populations into sub-species. DNA of the various populations was extracted from the foot muscle using CTAB (Cetyl Trimethyl Ammonium Bromide) method, which was subjected to RAPD analysis. The RAPD studies employed five (5) oligonucleotide primers (OPB - 17, OPH - 12, OPH - 17, OPI - 06 and OPU - 14) to amplify DNA from 27 samples of $A$. marginata selected. All five primers produced different band patterns, and the number of fragments amplified per primer varied. Among them, OPB- 17 gave DNA profiles with more numerous bands than the others primers. Both PCA and CVA produced overlapped clusters of $A$. marginata specimens from the three vegetation zones. The height of shell was observed to be the most variable feature and preferably the most suitable parameter for population grouping. Analysis of the proportions of polymorphic loci and band sharing based on similarity indices for $A$. marginata samples indicated a relatively high level of genetic variation in the populations from the three areas.
\end{abstract}

Keywords: amplification, delimitation, genetics, measurements, shell morphology, sub-populations

\section{Introduction}

Archachatina marginata (Swainson, 1821) is a land snail of the family Achatinidae. It is a giant land snail native to Africa (Raut and Barker, 2002). Generally, classification within the family is based on conchological features (Bequaert, 1951) and the highly variable reproductive tract (Mead, 1991). However, Bequaert (1951) reported the presence of subspecies of Archachatina marginata in Nigeria. In his studies on the Achatininae, a group of African land snails, he stated that $A$. marginata covers a wide territory, extending at least from Dahomey to the Lower and middle Belgian Congo, and possibly in French Equitorial Africa to the Gribingui River (about $7^{\circ} \mathrm{N}$., $\left.19^{\circ} \mathrm{W}\right)$. As a result, it has produced several intra specific variations, sometimes well segregated geographically, but more overlapping, yet well worthy of varietal or subspecific names.

The races are well developed by colour peculiarities and in some cases also by the average size or the general shape. All of them have retained the characteristic microsculpture. As they frequently occur in the same territory with specimens of the typical race, although perhaps in a different type of environment, it is not surprising that connecting examples occur in some localities. Among those, Bequaert (1951) listed as available in West African sub region are $A$. marginata ovum, $A$. marginata suturalis, $A$. marginata eduardi, $A$. marginata egregiella, $A$. marginata egregia, $A$. marginata clenchi, $A$. marginata icterica, $A$. marginata grevillei and $A$. marginata candefacta.

There are sub-species of $A$. marginata in Nigeria that despite all efforts made are still not morphologically separated. Effort to use morphometric parameters to separate $A$. marginata into subpopulations across three zones of Nigeria could also not indicate the presence of sub-species (Awodiran, 2012). However, molecular phylogeny of four species of land snails and eight subpopulations of $A$. marginata showed potentiality to diverge into sub-species (Awodiran, 2012). There is dearth of information on the genetic variability of this species in Nigeria. Recently, Okon et al. (2013) genetically differentiated the black skinned and white skinned snails, which termed ecotypes of $A$. marginata, using RAPD and concluded that the genetic variability of the species from Cross River State in Nigeria is gradually eroding.

Though, $A$. marginata is not listed as a threatened species of land snails, but loss of natural habitat over exploitation for diverse uses and the effect of climate change are serious concerns for its 
Table 1. Locations and sample size (n) for Archachatina marginata

\begin{tabular}{lccc}
\hline Vegetation Zone & Locality & $\begin{array}{c}\text { Geographical } \\
\text { coordinates }\end{array}$ & $\begin{array}{c}\text { Sample size } \\
\text { (n) }\end{array}$ \\
\hline Rainforest & Ife (If) & $7^{\circ} 28^{\prime} \mathrm{N} 4^{\circ} 34^{\prime} \mathrm{E}$ & 39 \\
Mangrove rainforest & Yenagoa $(\mathrm{Yn})$ & $4^{\circ} 50^{\prime} \mathrm{N} 6^{\circ} 15^{\prime} \mathrm{E}$ & 40 \\
Guinea savanna & Kabba $(\mathrm{Kb})$ & $7^{\circ} 50^{\prime} \mathrm{N} 6^{\circ} 4^{\prime} \mathrm{E}$ & 40 \\
Total & & & 119 \\
\hline
\end{tabular}

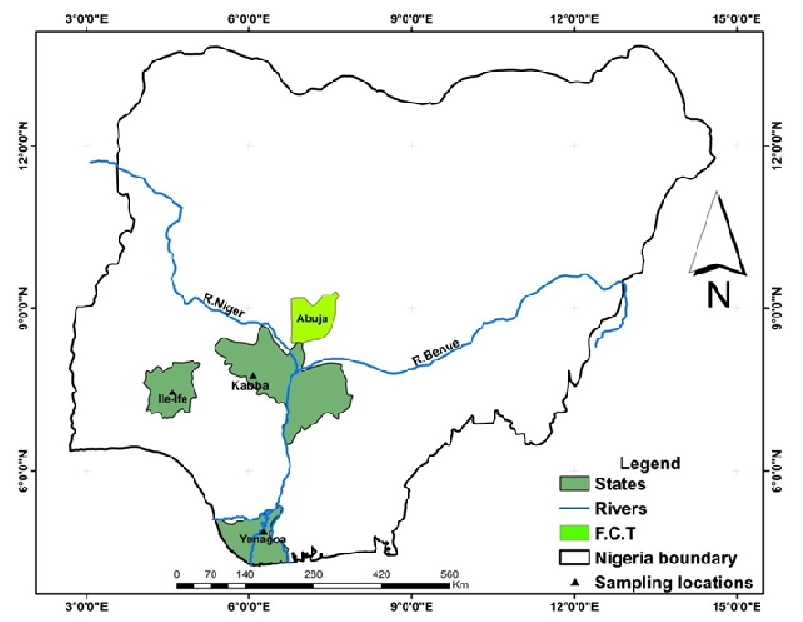

Fig. 1. Map of Nigeria showing sampling locations

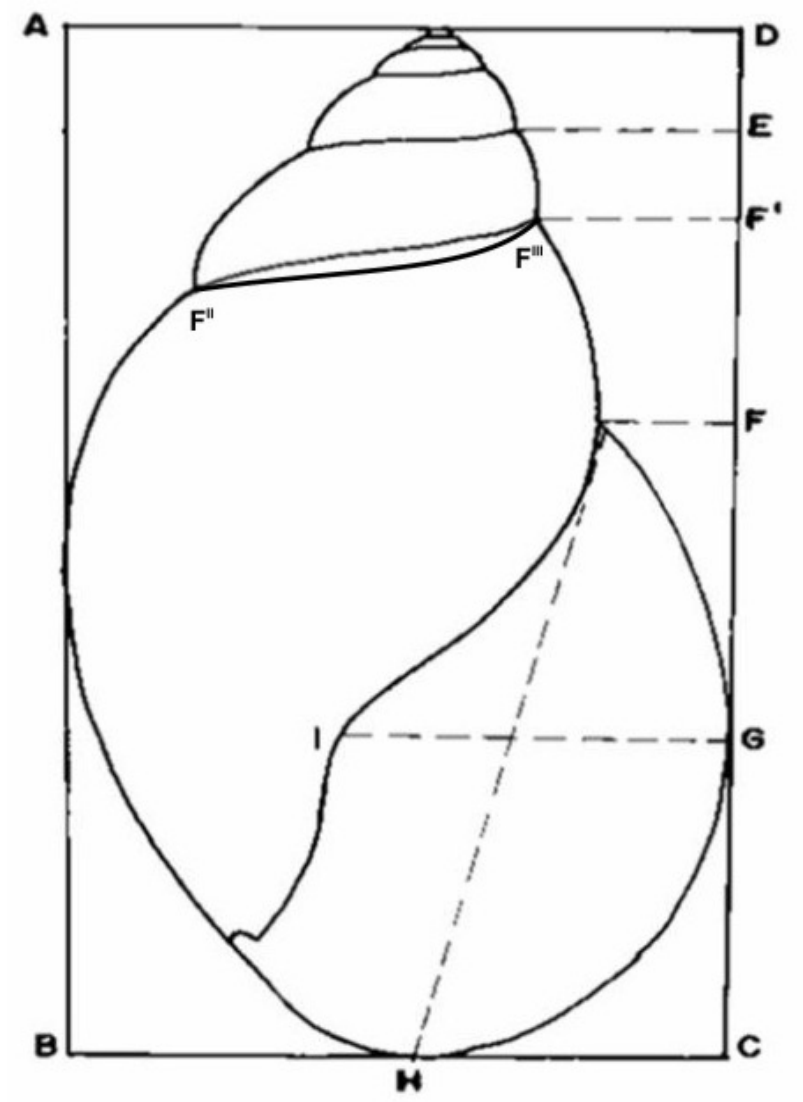

Fig. 2. Measurements of shell morphology used in multivariate analyses $(\mathrm{AB}=$ Height of Shell, HS; $\mathrm{BC}=$ Width of shell, WS; $\mathrm{DF}=$ Spire length, SL; F ${ }^{\mathrm{II}} \mathrm{F}^{\mathrm{III}}=$ Spire Width, SW; $\mathrm{EF}^{1}=1^{\text {st }}$ whorl length, 1WL; $\mathrm{FH}=$ Aperture height, $\mathrm{AH}$ and $\mathrm{GI}=$ Aperture Width, AW) decline and drastic loss of populations in Nigeria (Osemeabo, 1992; Okon et al., 2009). There is therefore a need to conserve the genetic resources of the species and its possible sub-species. Thus, an attempt was made in this study to employ the use of morphometrics and RAPD analysis to differentiate populations of $A$. marginata into sub-species.

\section{Materials and Methods}

\section{Study areas and sample collection}

Samples of $A$. marginata were collected from three different locations representing three different vegetation zones. The locations in Nigeria are Ile-Ife, Kabba and Yenagoa. Ile-Ife (Osun State) lies within the tropical zone and in the rainforest region of Nigeria; it has an average annual rainfall of $1,348 \mathrm{~mm}$. Kabba (Kogi State) has vegetation consisting of mixed leguminous (Guinnea) woodland to forest Savanna, with annual rainfall ranging from $1,016 \mathrm{~mm}$ to $1,524 \mathrm{~mm}$. Yenagoa (Bayelsa State) has a vegetation characterized by mangrove forest with heavy rainfall and a short dry season (usually from November to March) and has annual rainfall ranging from 2,000 $\mathrm{mm}$ to 4,000 $\mathrm{mm}$. The various locations sampled were illustrated in Fig. 1, while the sample size and the geographical coordinates were listed in Table 1.

One hundred and nineteen (119) snail specimens were collected, comprising of forty (40) specimens from each location in Yenagoa and Kabba and thirty nine (39) specimens were from Ile-Ife. The samples were purchased fresh from local farmers. The samples were then taken to the Genetics Laboratory, Department of Zoology, Obafemi Awolowo University, Ile-Ife for morphometric analysis. From each location, nine (9) snail specimens were selected and taken to the Central Laboratory/Biotechnology Centre, Federal University of Agriculture, Abeokuta, Ogun State, Nigeria for RAPD-PCR analysis.

\section{Morphometric studies}

To select characters for morphometric analyses, the available taxonomic descriptions from literature were reviewed (Brandt, 1974; Liu et al., 1979; Burch, 1980) and parameters of the shell that were of practical use in identification were adopted. The results of morphometric analyses might directly reflect the importance and effect of each character. A total of 8 shell measurements were taken with Vernier calipers on each of the snail shell. Shell length (HS) was measured along an axis passing through the apex to the bottom of the shell. Shell width (SW) is the maximum width perpendicular to the shell length distance. Aperture length $(\mathrm{AL})$ is the length from the beginning of the 1st suture to the bottom of the aperture. Aperture width (AW) is the maximum diameter perpendicular to the aperture length. The penultimate whorl length (PWL) is the length between the beginnings of the 1st suture to the beginning of the 2 nd suture. First whorl length was also measured (FWL). Spire length (SL) was measured from the beginning of the 1st suture to the apex of the shell. Spire width (SW) which is the maximum diameter of the spire from the first suture was also measured (Madec and Bellido, 2007). Fig. 2 shows measurements of shell morphology used in multivariate analyses.

\section{Statistical analysis}

Measurements of each morphometric character were transformed to shell width (SW) to remove size-effect by growth allometry using the method of Reist (1985) as described in 
374

Table 2. Code sequences and nucleotide lengths used in the RAPD analysis

\begin{tabular}{lcc}
\hline Primers & Primer Sequence $\left(5^{\prime}-3^{\prime}\right)$ & Nucleotide Length \\
\hline OPB-17 & AGGGAACGAG & 10 -mer \\
OPH-12 & ACGCGCATGT & 10 -mer \\
OPH-17 & CACTCTCCTC & 10 -mer \\
OPI-06 & AAGGCGGCAG & $10-$ mer \\
OPU-14 & TGGGTCCCTC & $10-\mathrm{mer}$ \\
\hline
\end{tabular}

Gunawickrama (2007). Width corrected data were then analyzed by multivariate statistical method. A multivariate Cluster Analysis was carried out on the morphometric data obtained to illustrate patterns of correlation among populations from various locations (Chiu et al., 2002; Madec et al., 2003). A Canonical Variates Analysis and Student's t-test were subsequently carried out to observe if species and populations from the various ecological zones were significantly different and to identify morphometric characters by which these operational taxonomic units could be diagnosed. The analysis was carried out with the aid of statistics software PAST (Hammer $e t$ al., 2006).

\section{Genomic DNA extraction}

The genomic DNA of the snail was isolated using CTAB (Cetyl Trimethyl Ammonium Bromide) method. The snail specimen preserved in ethanol was grinded in the mortar and 600 $\mu l$ of extraction buffer was added to the sample, which was then incubated in the water bath at $65^{\circ} \mathrm{C}$ for 30 minutes. The sample was removed and allowed to cool to room temperature after which chloroform was added and the sample was mixed by gently inversion of the tube several times. Thereafter, the sample was spun at 14,000 $\mathrm{rpm}$ for 15 minutes and the supernatant was transferred into a new Eppendorf tube and equal volume of cold Isopropanol was added to precipitate the DNA. The sample was kept in the freezer for 1 hour later centrifugated at 14,000 rpm for 10 mins and the supernatant was discarded and the pellet was washed with $70 \%$ Ethanol; the obtained sample was air dried for 30 mins on the bench. The pellet was resuspended in $100 \mu \mathrm{l}$ of sterile distilled water. DNA concentration of all the samples was measured on spectrophotometer at $260 \mathrm{~nm}$ and $280 \mathrm{~nm}$ and the genomic purity were determined. The quality of DNA was detected by Agarose gel electrophoresis. The genomic DNA was used in PCR amplification using RAPD markers. Code sequences and nucleotide lengths used in RAPD studies are shown in Table 2.

\section{DNA electrophoresis}

Agarose gel electrophoresis was used to determine the quality and integrity of the DNA by size fractionation on 1.0\% Agarose gels. Agarose gels were prepared by dissolving and boiling $1.0 \mathrm{~g}$ Agarose in $100 \mathrm{ml} 0.5 \mathrm{XTBE}$ (Trisic Boric Acid) buffer solution. The gels were allowed to cool to about $45^{\circ} \mathrm{C}$ and $10 \mu \mathrm{l}$ of 5 $\mathrm{mg} / \mathrm{ml}$ Ethidium Bromide were added, mixed together before pouring the solution into an electrophoresis chamber set with the combs inserted. After the gel has solidified, $3 \mu$ l of the DNA with $5 \mu \mathrm{l}$ sterile distilled water and $2 \mu \mathrm{l}$ of $6 \mathrm{X}$ loading dye were mixed together and loaded in the well created. Electrophoresis was done at $80 \mathrm{~V}$ for 2 hours. The integrity of the DNA was visualized and photographed on UV (Ultra Violet) light source.

\section{$P C R$ reaction mix}

$10 \mu \mathrm{l}$ of each DNA supernatant were taken into Eppendorf tube and $990 \mu \mathrm{l}$ sterile distilled water was added to make the final volume of $1000 \mu$ l. The final concentration of the dilution of DNA for PCR became $20-50 \mathrm{ng} / \mu \mathrm{l}$.
The reaction mix was carried out in $20 \mu \mathrm{l}$ final volume containing 60-80 ng genomic DNA, $0.1 \mu \mathrm{M}$ of the primers, 2 $\mathrm{mM} \mathrm{MgCl}, 125 \mu \mathrm{M}$ of each dNTP (di Nucleotide Triphosphate) and 1 unit of Taq DNA polymerase. The thermocycler profiles had an initial denaturation temperature of $94{ }^{\circ} \mathrm{C}$ for 3 mins, followed by 45 cycles of denaturation temperature of $94^{\circ} \mathrm{C}$ for 20 seconds, annealing temperature of $37^{\circ} \mathrm{C}$ for 40 seconds and primer extension temperature of $72^{\circ} \mathrm{C}$ for 40 seconds, followed by final extension temperature at $72^{\circ} \mathrm{C}$ for 5 minutes.

\section{Gelelectrophoresis}

PCR amplicon electrophoresis was carried out by size fractionation on $1.4 \%$ Agarose gels. Agarose gels were prepared by dissolving and boiling $2.8 \mathrm{~g}$ agarose in $200 \mathrm{ml} 0.5 \mathrm{X}$ TBE (Trisic Boric Ethylenediamine Tetra-acetic Acid) buffer solution. The gels were allowed to cool to about $50^{\circ} \mathrm{C}$ and $10 \mu \mathrm{l}$ of $5 \mathrm{mg} / \mathrm{ml}$ Ethidium Bromide were added, mixed together before pouring into an electrophoresis chamber set with the combs inserted. After the gel has solidified, the PCR amplicon was loaded in the well created. Electrophoresis was done at $100 \mathrm{~V}$ for 2 hours. The DNA was visualized and photographed on UV light source.

\section{Band scoring and data analysis}

Each gel was analyzed by scoring the present $(1)$ or absent $(0)$ polymorphic bands in individual lanes. The scoring was done based on the banding profiles which were clear and transparent. The scores were then pooled for constructing a single data matrix. Purity of the DNA was carried out using spectrophotometer by measuring absorbance at $260 \mathrm{~nm}$ and 280 $\mathrm{nm}$. The RAPD banding profiles were visually scored for all the DNA samples and for each primer. Similarity coefficients were calculated across all the possible pair wise comparisons of snail samples among populations, using the formula below:

$$
S x y=\frac{2 n x y}{n x+n y}
$$

Where, nxy is the number of common bands shown in both individuals $\mathrm{x}$ and $\mathrm{y}$, and $\mathrm{nx}$ and ny are the total numbers of bands observed in individuals $\mathrm{x}$ and $\mathrm{y}$ respectively.

As a mean of providing visual representation of genetic relationships, a dendrogram was constructed based on the similarity coefficient values ( 1 - Sxy) between pairs of snail samples. The NTSYS-PC software program was used to estimate genetic similarities with the Jaccard's coefficient (Rohlf et al., 2000) and a dendrogram was constructed using the Unweighted Pair Group Method of Arithmetic Averaging (UPGMA) employing the Sequential, Agglomerative, Hierarchical and Nested clustering module (SAHN).

\section{Results}

\section{Morphometric studies}

The average values, ranges and standard errors for all the shell variables measured are shown in Table 3 . Wide range of sizes, especially on height of shell and width of shell, were found in the samples of Ile-Ife (Height of Shell SD $16.63 \mathrm{~cm}$ and $9.29 \mathrm{~cm}$, respectively), revealing great heterogeneity in the population. The standard deviations for all Height of Shell, 


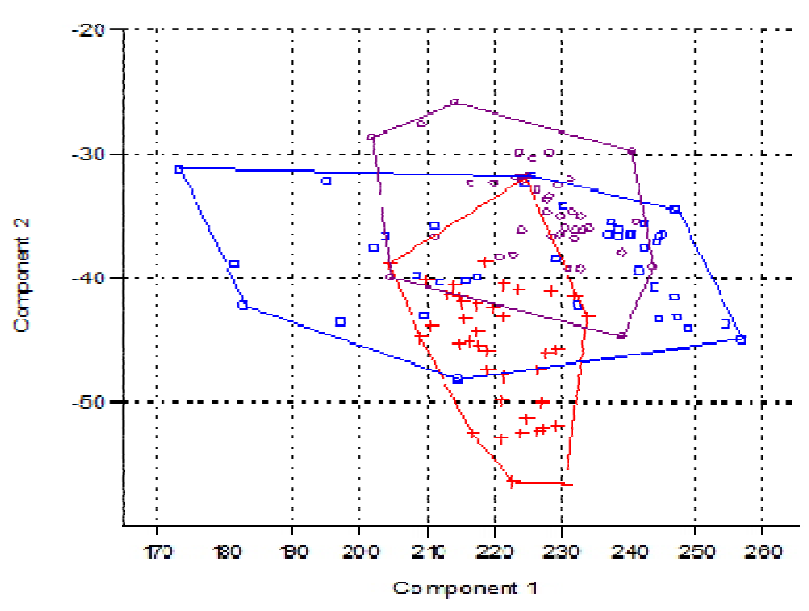

Fig. 3. Principal Components Analyses based on Archachatina marginata shell measurements of snails from Yenagoa (red + ), Ile-Ife (blue $\square$ ) and Kabba (purple o) showing overlap of the three populations under study

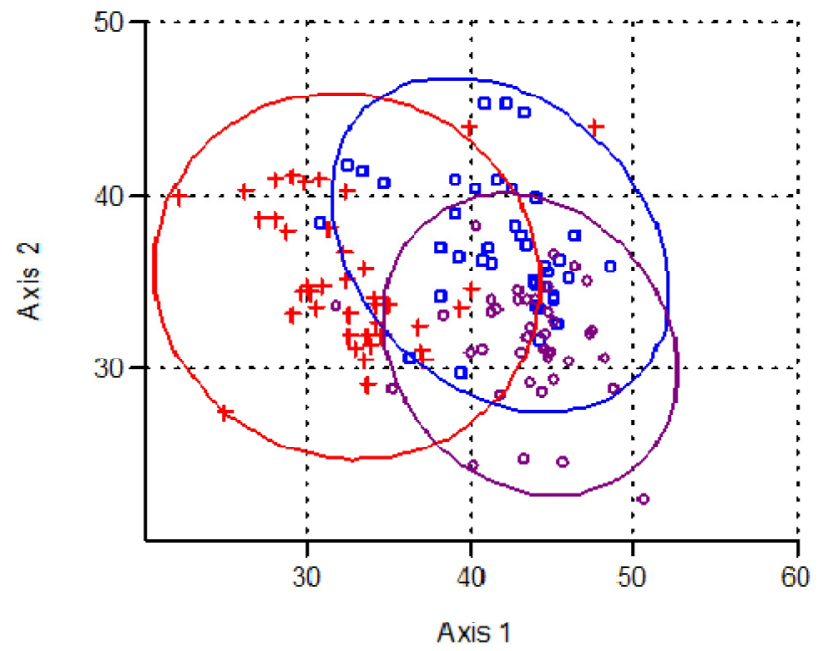

Fig. 4. Canonical Variates Analyses based on Archachatina marginata shell measurements of snails from Yenagoa (red + ), Ile-Ife (blue $\square$ ) and Kabba (purple o) showing overlap of the three populations under study

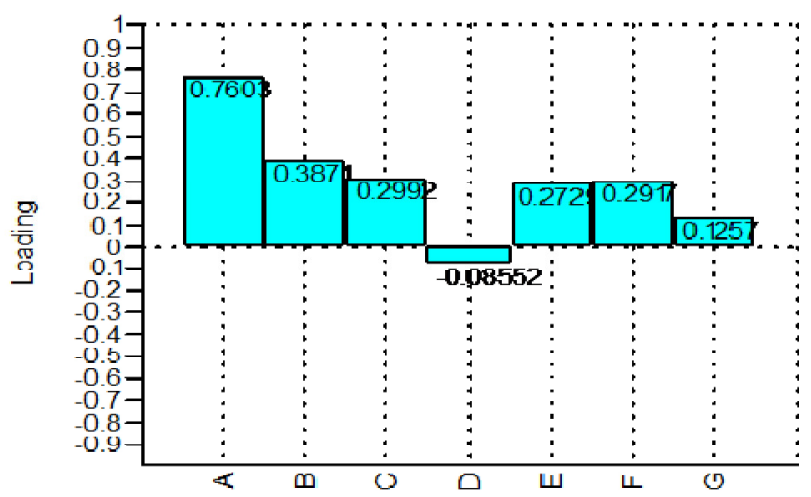

Fig. 5. Respective snail shell characters and their loadings on PC1 of the Principal Components Analysis $(\mathrm{A}=\mathrm{HS}, \mathrm{B}=\mathrm{AH}$, $\mathrm{C}=\mathrm{AW}, \mathrm{D}=\mathrm{SL}, \mathrm{E}=\mathrm{SW}, \mathrm{F}=1 \mathrm{WL}, \mathrm{G}=\mathrm{PWL}$ ) for all the populations under study, were found to be higher than other parameters measured.

The principal component analyses of the 8 morphometrics measurements of $A$. marginata shells from the three areas of study were shown in Fig. 3. All the three clusters produced by the Principal Components Analysis (PCA) overlapped. Canonical Variates Analyses (CVA) was conducted to see if the population of $A$. marginata collected from the three locations could be separated intra specifically (Fig. 4).

The CVA plots showed the overlapping of clusters of the specimens from the three different locations studied. Fig. 5 showed the respective snail shell characters and their loadings on PCI, which evidenced that the characteristic responsible for most of the variation among the populations of $A$. marginata was the shell height.

Data obtained for the analyzed characteristics were also compared in box plots as shown in Fig. 6. These box plots represent summaries of measurements of the three highest loading characters, which were Shell height, Aperture height and Aperture width in the Principal Component Analysis.

The clustering pattern of $A$. marginata specimens from across the three vegetation zones was revealed in a dendrogram (Fig. 7).

\section{RAPD results}

\section{$D N A$ profiles generated by RAPD primers}

The Genomic DNA purity ranged between 1.8 and 2.0 for all the samples. The size of the DNA obtained was $25 \mathrm{~kb}$ for all the samples. Random Polymorphic DNA analysis was performed on genomic DNA samples of snails from three locations in the three zones using five 10 base pairoligonucleotide random primers which showed different numbers of stable amplification and polymorphism bands. Fig. 8 shows the electrophoresis gel for DNA obtained for the 27 samples from the three locations (Samples 1 - 9 = Ile-Ife, Samples $10-18$ = Kabba, Samples 19 - 27 = Yenagoa). Figs. 9, 10, 11, 12 and 13 show the electrophoresis gels for the five primers used for PCR amplifications namely OPB - 17, OPH - 12, OPH - 17, OPI - 06 and OPU - 14 respectively. All five primers produced different RAPD banding patterns and the number of fragments amplified per primer varied. No band was population specific and the average number of bands per primer was 14 . Among the primers, OPB - 17 gave the DNA profiles with more numerous bands as shown in Table 3. The total number of fragments yielded from five primers were 71 , of which 40 (56.3\%) were polymorphic. The total number of RAPD bands produced in populations from Ile-Ife, Kabba and Yenagoa was of 71 bands, out of which 32, 13 and 19 bands were polymorphic for each population ( $45.1 \%, 18.3 \%$ and $26.8 \%$ respectively). Table 4 shows the list of the primers used, the number of polymorphic and monomorphic loci, total number of loci and the percentage polymorphism.

Dendrogram showing the cluster analysis of the individuals' genotype was presented in Fig. 14. Four major clusters were formed as per the dendrogram which consists of minor clusters at various degrees of coefficient of the phylogenetic analysis. The UPGMA (Unweighted Pair Group Method of Arithmetic Averaging) cluster diagram identified four major genotypic groups with inter and intra group relationships. At coefficient 1 (100\%), a cluster was formed between samples from Kabba 3 and 8, and Ile-Ife 1,2, 4 and 8, indicating a very high level of genetic similarity. The first cluster consisted of samples mainly 

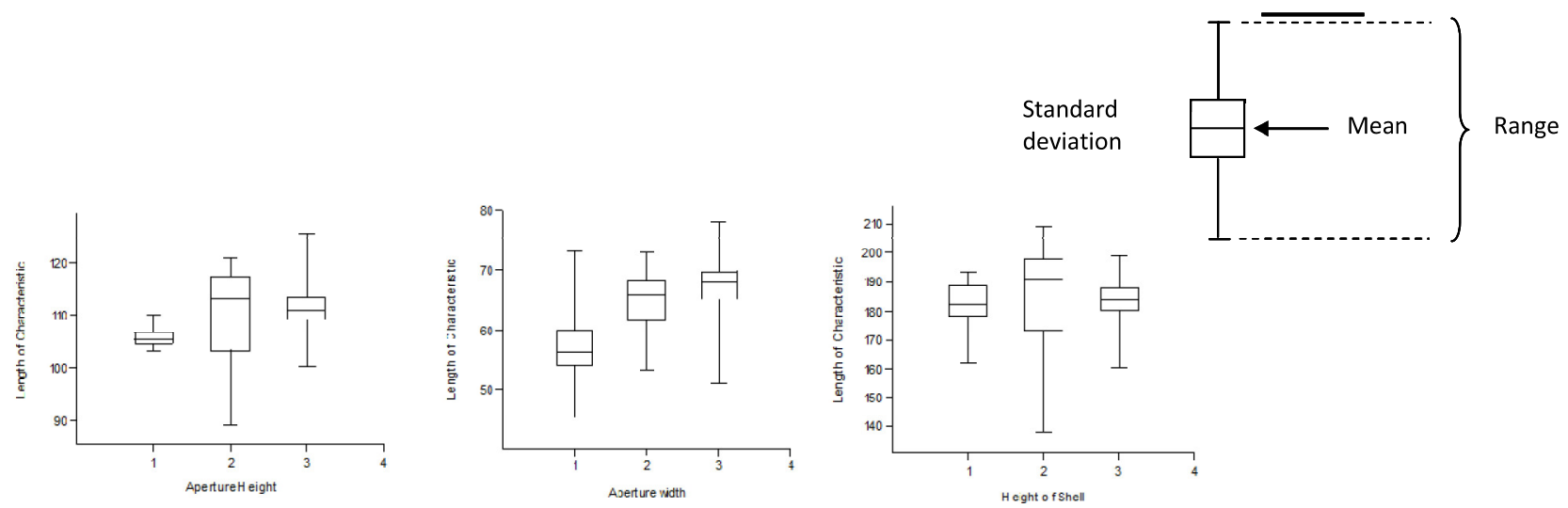

Fig. 6. Box plots of morphometric characteristics for Archachatina marginata from three different locations (Yenagoa = 1, Ile-Ife $=2$ and Kabba = 3) for three different characteristics viz. Height of shell, Aperture Height and Aperture Width

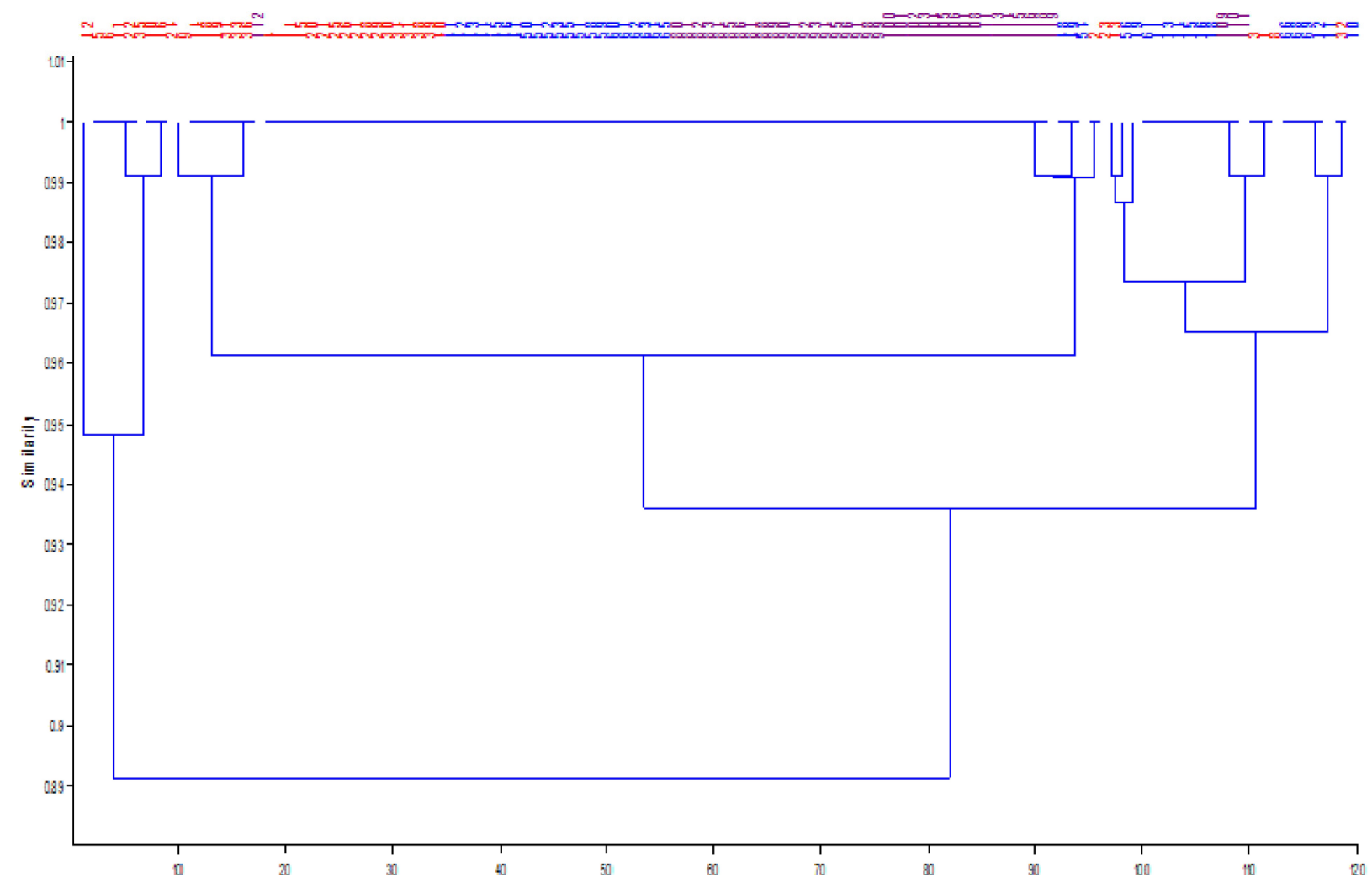

Fig. 7. Dendrogram showing relationship between the three populations of $A$. marginata from Ile-Ife: (Blue), Kabba: (Red) and Yenagoa: (purple)

from Kabba (Kabba 4, 5, 6 and 7). The second cluster was made of Yenagoa 3, 5, 9, 8, and Ile-Ife 5 and 9. The third cluster consisted of Yenagoa 2, Kabba 3, 8, 1, Ile-Ife 3, 1, 2, 4, 8, 7 and 6, and also Kabba 9, Yenagoa 6 and 7, while the fourth cluster consisted of Yenagoa 1, 4 and Kabba 2.

The dendrogram basically showed two major groups. The first group had a larger number mainly nine (9) samples from Yenagoa (Yenagoa 1, 4, 2, 6, 7, 3, 5, 9 and 8), nine (9) samples from Ile-Ife (Ile-Ife 3, 1, 2, 4, 8, 7, 6, 5 and 9) and five (5) samples from Kabba (Kabba 2, 3, 8, 1 and 9) making a total of 23 samples in the group. The second group had only four (4) samples from
Kabba region (Kabba 4, 5, 6 and 7). The first group can be subdivided into two (2) major subgroups, the first subgroup comprising five (5) samples from Yenagoa (Yenagoa 1, 4, 2, 6 ,) seven (7) samples from Ile-Ife (Ile-Ife 3, 1, 2, 4, 8, 7, 6) and five (5) samples from Kabba (Kabba 2, 3, 8, 1 and 9). The second subgroup comprised of four (4) samples from Yenagoa (Yenagoa 3, 5, 9 and 8) and two (2) samples from Ile - Ife (Ile-Ife 5 and 9).

The values of pair-wise comparisons of Nei's (1978) unbiased genetic distances (D) between populations, computed from the combined data for the five primers, 


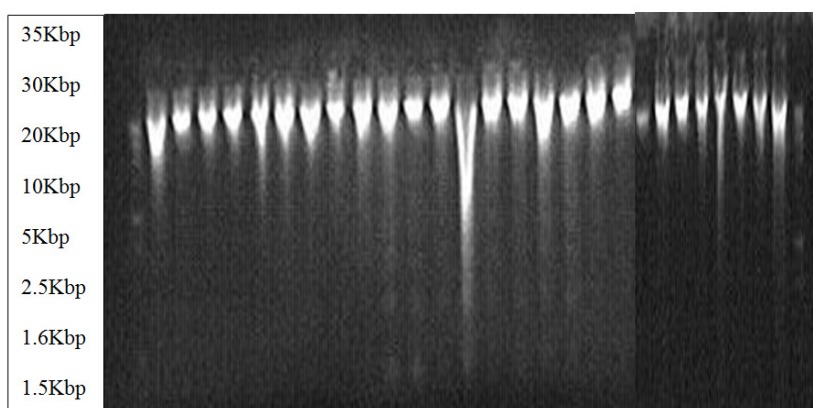

Fig. 8. Electrophoretic gel photograph of the 27 samples of $A$. marginata DNA; samples 1 - 9 are from Ile-Ife, samples 10 - 18 are from Yenagoa, while samples 19 - 27 are from Kabba; Kbp kilo base pair and bp - base pair

$$
\text { M } 123456789101112131415161718192021222324252627
$$

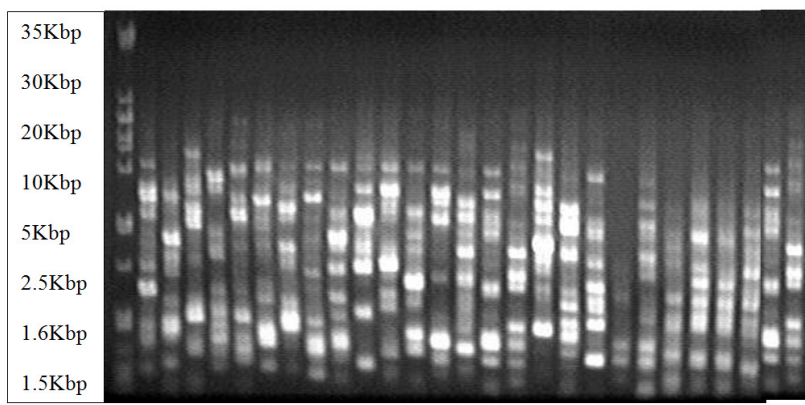

Fig. 9. RAPD banding profile of 27 samples of $A$. marginata population for Primer OPB - 17; samples 1 - 9 = Ile-Ife, samples $10-18=$ Yenagoa, samples $19-27=$ Kabba; Kbp kilo base pair and $\mathrm{bp}$ - base pair

M 123456789101112131415161718192021222324252627

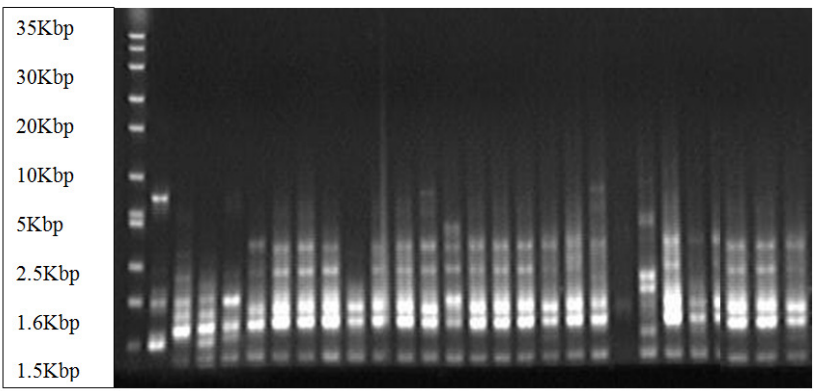

Fig. 10. RAPD banding profile of 27 samples of $A$. marginata using OPH - 12 primer; samples 1 - 9 = Ile-Ife, samples 10 18 = Yenagoa, samples 19 - 2=Kabba; Kbp - kilo base pair and bp - base pair

ranged from 0.54 to 0.63 . Samples from Ile-Ife were the most genetically distinct as population, which was segregated from Kabba population with the $\mathrm{D}$ value of 0.63 and from Yenagoa population with the $\mathrm{D}$ value of 0.58 . Yenagoa and Kabba populations were separated from each other with the lowest genetic distance $D$ value of 0.54 . Genetic differences between populations exhibited a consistent

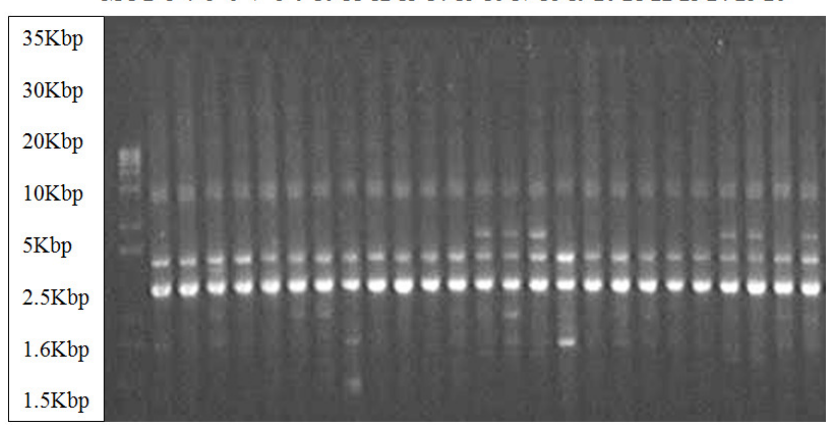

Fig. 11. RAPD banding profile of 27 samples of $A$. marginata using $\mathrm{OPH}-17$ primer; samples 1 - 9 = Ile-Ife, samples 10 18 = Yenagoa, samples $19-2$ = Kabba; Kbp - kilo base pair and bp - base pair

M 123456789101112131415161718192021222324252627

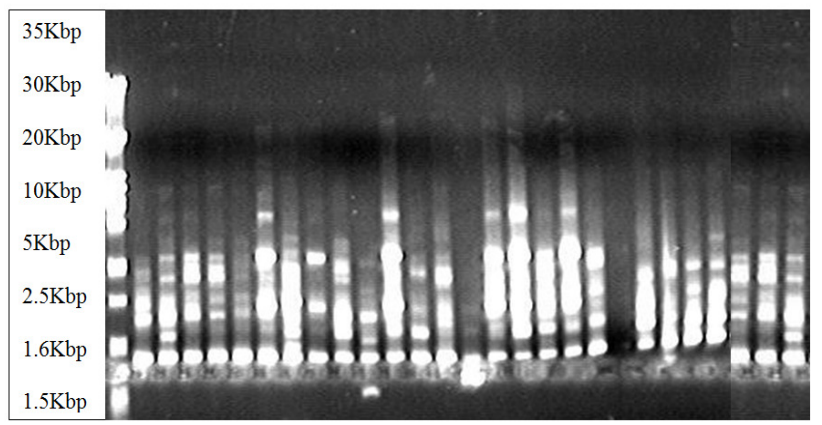

Fig. 12. RAPD banding profile of 27 samples of $A$. marginata using OPI - 06 Primer; samples 1 - 9 = Ile-Ife, samples 10 - 18 = Yenagoa, samples 19 - 27 Kabba; Kbp - kilo base pair and bp - base pair

M1 2 34556789101112131415161718192021222324252627

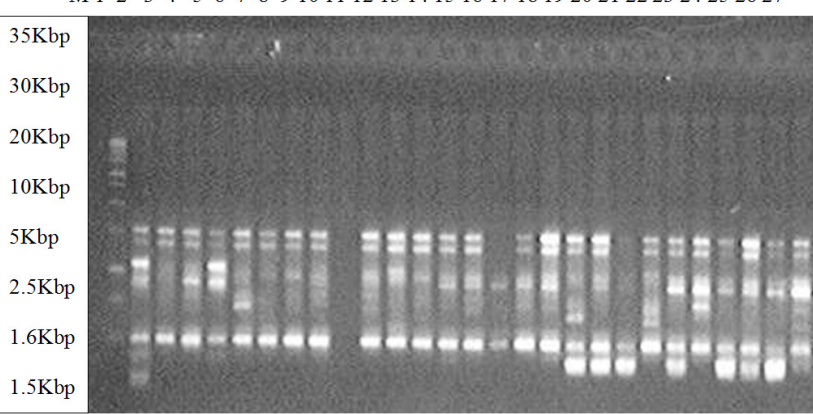

Fig. 13. RAPD banding profile of 27 samples $A$. marginata using OPU - 14 Primer; samples 1 - 9 = Ile-Ife, samples 10 $18=$ Yenagoa, samples $19-27=$ Kabba; Kbp - kilo base pair and bp - base pair

geographical pattern clearly illustrated in the UPGMA dendrogram based on Nei's genetic distance as shown in Fig. 14. However, all the groups had various interrelationships showing highly heterogeneous populations. The cluster between $A$. marginata population from Kabba and Yenagoa implied that these populations are more similar genetically than to those of the Ile-Ife population (Fig. 15). 
Table 3. The Range of Mean (R), Mean (X) and Standard Deviation (SD) of each morphometric variable of $A$. Marginata from the three different locations

\begin{tabular}{lcccc}
\hline Variables $(\mathrm{cm})$ & & Ile-Ife & Kabba & Yenagoa \\
\hline $\mathrm{N}$ & & 39 & 40 & 40 \\
$\mathrm{HS}$ & $\mathrm{R}$ & $138-208.57$ & $160.00-198.41$ & $161.29-192.98$ \\
& $\mathrm{X}$ & 184.66 & 182.70 & 182.04 \\
& $\mathrm{SD}$ & 16.63 & 8.06 & 6.56 \\
$\mathrm{WS}$ & $\mathrm{R}$ & $88.89-120.73$ & $100.00-125.53$ & $103.18-109.84$ \\
& $\mathrm{X}$ & 109.43 & 111.03 & 105.62 \\
& $\mathrm{SD}$ & 9.29 & 4.32 & 1.72 \\
$\mathrm{AL}$ & $\mathrm{R}$ & $53.33-72.97$ & $50.85-77.78$ & $45.16-73.08$ \\
& $\mathrm{X}$ & 64.68 & 67.10 & 57.20 \\
& $\mathrm{SD}$ & 5.18 & 4.79 & 5.38 \\
$\mathrm{AW}$ & $\mathrm{R}$ & $42.67-70.27$ & $40.43-60.94$ & $46.27-61.40$ \\
& $\mathrm{X}$ & 52.59 & 48.05 & 52.76 \\
& $\mathrm{SD}$ & 6.43 & 3.81 & 3.67 \\
PWL & $\mathrm{R}$ & $40.24-65.7$ & $37.93-65.96$ & $41.82-63.16$ \\
& $\mathrm{X}$ & 53.48 & 54.35 & 55.74 \\
& $\mathrm{SD}$ & 7.67 & 4.54 & 3.63 \\
FWL & $\mathrm{R}$ & $26.0-50.0$ & $31.91-45.45$ & $17.46-52.73$ \\
& $\mathrm{X}$ & 40.63 & 37.89 & 34.67 \\
\hline
\end{tabular}

Table 4. Total number of RAPD fragments and the percentage polymorphic fragments generated by five primers in A. marginata populations from Ile-Ife, Yenagoa and Kabba

\begin{tabular}{|c|c|c|c|c|}
\hline \multirow{2}{*}{ Primers } & No. of Polymorphic & No. of Monomorphic & \multirow{2}{*}{ Total no. of Loci } & \multirow{2}{*}{ \%Polymorphism } \\
\hline & Loci & Loci & & \\
\hline OPB - 17 & 24 & 2 & 26 & 92 \\
\hline $\mathrm{OPH}-12$ & 7 & 4 & 11 & 64 \\
\hline $\mathrm{OPH}-17$ & 5 & 4 & 9 & 56 \\
\hline OPI - 06 & 13 & 2 & 15 & 87 \\
\hline OPU -14 & 7 & 3 & 10 & 70 \\
\hline Total & 56 & 15 & 71 & \\
\hline
\end{tabular}

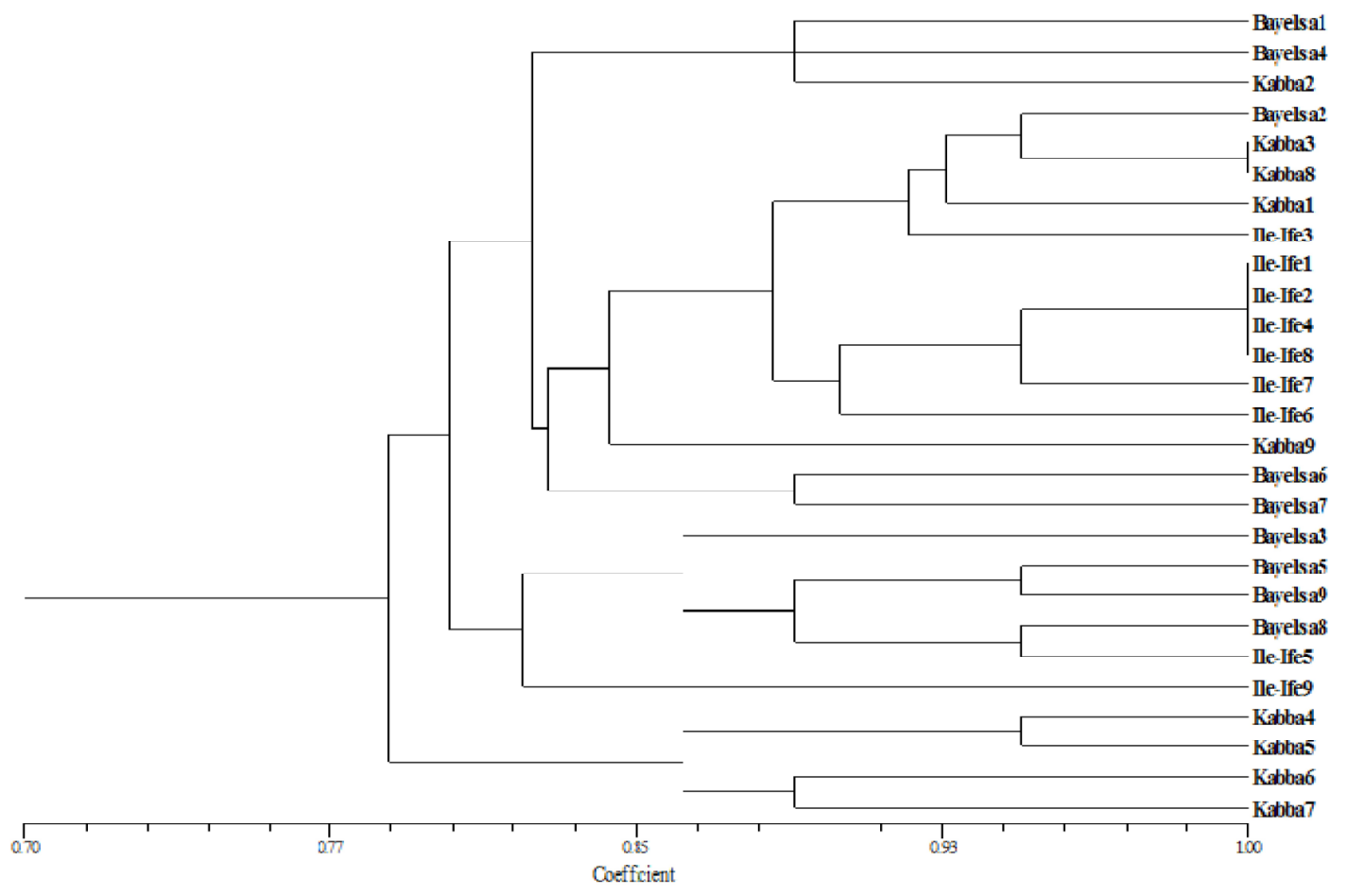

Fig. 14. Neigbour - joining dendrogram showing the genetic relationship between $A$. marginata from three vegetation zones of Nigeria: Rainforest (Ile-Ife), Mangrove forest (Yenagoa) and Guinea Savanna (Kabba) 


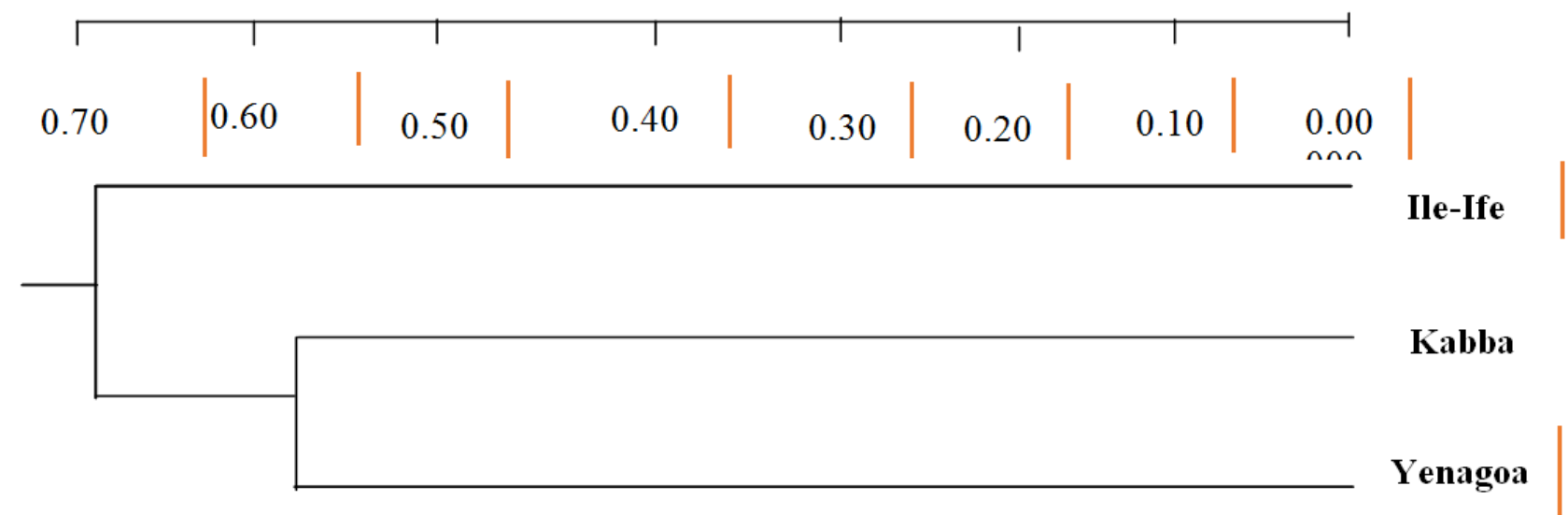

Fig. 15. UPGMA dendrogram based on Nei’s (1978) unbiased genetic distance, summarizing the data on differentiation between A. marginata populations according to RAPD analysis

\section{Discussion}

All the clusters produced by the Principal Component Analysis on the parameters measured on $A$. marginata overlapped; also Canonical Variates Analysis plots that were produced showed overlapping of specimens clusters. Madec and Bellido (2007) reported that both genetic and environmental factors and the interplay of both are responsible for the development of shell characteristics. Chiu et al. (2002) also reported that extrinsic factors due to environmental conditions can induce variations in the shell shape and size. They also argued that environmental changes without genetic variation can create distinct nongenetic changes in shell morphology. Canonical Variates Analysis also did not separate the samples into distinct subpopulations due to the fact that there was a considerable overlap. A. marginata samples from Mangrove forest (Yenagoa) therefore showed a small cluster with lower values. Out of the measured parameters, shell height was found to be the most variable and thus the most suitable for populations' grouping. Awodiran et al. (2013) also reported the height of shell as the parameter most responsible for variation out of eight morphometric characters employed in the three populations of $A$. marginata. Results obtained from the morphometric studies hence showed that morphometric methods are effective to some reasonable extent in separating populations of land snails at interspecific level.

RAPD profiles are frequently used to analyze the genetic structure of populations of vertebrate and invertebrates (Gibbs et al., 1994; Apostol et al., 1996; Liao and Hsiao, 1998). RAPD technique is suggested to be more useful in closely related populations (Smith and Williams, 1994; Borowsky et al., 1995). This technique has been used as a molecular tool for detecting genetic variation and genetic similarity in several snail species including Scallop Chlamys farreri (LIU et al., 2004) species identification, Mollusca Clausiliidae Balea biplicata (Hille et al., 2003) and Littorina littorea (Hans De Wolf et al., 2013).
This study showed the effectiveness of RAPD in detecting polymorphism in different populations of $A$. marginata, and also in classifying different populations of the species into sub-populations, which could not be done by the application of morphometric analysis alone. Previous researchers have proved that RAPD is undoubtedly a powerful approach for the analysis of genetic variation and the identification of genetic markers (Barral et al., 1993; Simpson et al., 1993; Vidigal et al., 1994; Leamon et al., 2014). The results of this study also suggested OPB - 17 as an invaluable primer in detecting genetic polymorphism in populations of snail species due to the very high percentage of polymorphism recorded hereby. The OPA-17 marker was also used by various investigators on different organisms. For instance, Basavaraju et al. (2014) used the primer to determine the level of genetic heterogeneity between stocks of Labeo fimbriatus. The total number of fragments yielded from the five primers was 71 , out of which $40(56.3 \%)$ were polymorphic and the percentage of polymorphic loci was 45.1, 18.3 and $26.8 \%$ for populations of $A$. marginata in Ile-Ife, Kabba, and Yenagoa respectively. Analysis of the proportions of polymorphic loci and band sharing based similarity indices for $A$. marginata samples indicated that a relatively high level of genetic variation exists in the Ile-Ife population compared to Kabba and Yenagoa populations. The higher similarity and lower level of frequency of polymorphic loci and gene diversity estimates for Kabba and Yenagoa populations could be an indication of comparatively closer relationship among individuals in these populations. In other words, both populations were more homogenous than the Ile-Ife population.

Factors such as population size, bottlenecks and mutation, however may also influence genetic variability in populations. High level of polymorphism and genetic diversity is required for the adaptation of populations to the environmental changes. Bernardi et al. (2001) suggested that the genetic structure of organisms could be the result of habitat connectivity patterns, ecological 
380

conditions and dispersal potential. The influence of environmental factors also plays a decisive role in the differentiation of populations. Similarly, Bowditch et al. (1993) reported that detection of genetic variation is essential to a wide range of comparative genetic research endeavors which include gene mapping, individual identification, parentage determination, population genetics and molecular phylogenetics. As expected, the band-sharing based on similarity indices were higher within samples than other sample comparisons. This implied that the $A$. marginata population of one location is more homogenous than the combined group of the three populations. Therefore, the maintenance of genetic variability is very important for the conservation of a species (Barroso et al., 2005).

The UPGMA cluster diagram identified four major genotypic groups with inter and intra group relationships. All individuals in the first cluster are from Kabba region, while individuals from Yenagoa and Ile-Ife constitute a second cluster. The third cluster constitute individuals from Ile-Ife, Kabba and Yenagoa, while the forth cluster comprised individuals from Yenagoa and Kabba. However, all the groups had varied interrelationships, showing a highly heterogeneous population. The cluster between $A$. marginata populations from Ile-Ife and Yenagoa implied that these populations are more genetically similar than to those of Kabba population. Also, the cluster between Ile-Ife, Kabba and Yenagoa indicated that the three populations are genetically similar to some extent, while the cluster between Yenagoa and Kabba showed that the two populations are similar genetically. Dendrogram based on Nei's (1978) unbiased genetic distance showed that IleIfe and Yenagoa are closer genetically, while Kabba population is distant from them. The low level of genetic heterogeneity of both Yenagoa and Kabba samples may be because of recent origin of the populations. Both locations are geographically wide apart and the populations are therefore expected to be different genetically, hence it will be difficult to adduce reasons for the genetic homogeneity of the two populations. The high level of genetic homogeneity of the two populations may also be due to the limited number of individuals sample as the populations with similar genetic make-up needs large number of individuals and primers for precise differentiation of significant gene flow within each population (Basavaraju et al., 2014). Negel (1997) suggested that the high levels of migration and gene flow between populations increase the genetical similarity of populations.

Genetic drift and natural selection are the two primary evolutionary processes that cause population differentiation (Hufford and Mazer, 2003).

\section{Conclusions}

Out of the measured parameters, shell height was found to be the most variable and thus the most suitable for populations' grouping. Natural selection by ecological factors will result in development of ecological adaptation or ecotypes. It remains to be determined whether the observed population differentiation resulted from any natural selection. In addition, this genetic clustering prompted the question whether the four clusters of populations represent three different distribution zones of genetic diversity within the natural populations. If distribution zones do exist, additional questions would then be whether natural populations in each zone represent a regional ecotype, and what ecological factors contributed to this differentiation or adaptation.

\section{References}

Apostol BL, Black WC, Reiter P, Miller B (1996). Population genetics with RAPD-PCR marker: the breeding structure of Aedes aegypti in Puerto Rico. Heredity 76:325-334.

Awodiran MO, Olayemi AO, Awopetu JI (2012). Morphometric studies of land snails, A. marginata (Swainson, 1821) in some South-West, South-South and North Central States of Nigeria. International Journal of Academic Research 4(6):280-286.

Awodiran MO, Awopetu JI, Odekanyin OO, Ogunbosoye DO (2013). An electrophoretic study of protein diversity in five species of land snails (Achatinidae) from Nigeria. International Journal of Biological and Chemical Sciences 7(1):86-95.

Barral V, This P, Imbert-Establet D, Combes C, Denseny M (1993). Genetic variability and evaluation of Schistosoma genome analyzed by using Random Amplified Polymorphic DNA makers. Molecular Biochemistry and Parasitology 59:211-222.

Barroso RM, Hilsdorf AWS, Moreira HLM, Cabello PH, TraubCseko Y (2005). Genetic diversity of wild and cultured populations of Brycon opalinus (Cuvier, 1819) (Characiforme, Characidae, Bryconiae) using microsatellites. Aquaculture 247:51-65.

Basavaraju A, Narasimha R, Rajannua KB, Chethan N (2014). Random Amplified Polymorphic DNA (RAPD) analysis of three stocks of Labeo fimbriatus from Indian Pennisula. Global Journal of Bioscience and Biotechnology 3:278-283.

Bernardi G, Holbrook SJ, Schmittt RJ (2001). Gene flow at three spatial scales in a coral reef fish, the three-spot dyscyllus, Dascyllus trimaculatus. Marine Biology 138:457-465.

Bequaert JC (1951). Studies in the Achatininae, a Group of African land Snails. Bulletin of the Museum of Comparative Zoology at Harvard College 105(1):1-216.

Borowsky RL, McCelland M, Cheng R, Welsh J (1995). Arbitrarily primed DNA Fingerprinting for phylogenetic reconstruction in vertebrates: the Xiphophorus model. Molecular Phylogeny and Evolution 12:1022-1032.

Bowditch BM, Albright DG, Williams JGK, Braun MJ (1994). Use of Random Amplified Polymorphic DNA markers in comparative genome studies. Methods in Enzymology 224:294309.

Brandt RAM (1974). The non-marine aquatic mollusca of Thailand. Archiv fur Molluskenkunde 105:1-423.

Burch JB (1980). A guide to freshwater snails of the Philippines. Malacologia 13:121-143.

Chiu YW, Chen HC, Lee SC, Chen CA (2002). Morphometric analysis of shell and operculum variations in the viviparid snail Cipangopaludina chinensis (Mollusca): Gastropoda in Taiwan. Zoological Studies 41:321-341. 
Gibbs HL, Prior KA, Weatherhead PJ (1994). Genetic analysis of populations of threatened snake species using RAPD markers. Molecular Ecology 3:329-337.

Gunawickrama KBS (2007). Morphological heterogeneity in some estuarine populations of the catfish Arius jella (Ariidae) in Sri Lanka. Ceylon Journal of Science 36(2):100-107.

Hammer Ø, Harper DAT, Ryan PD (2006). PASTPalaeontological Statistical Software Package for education and data analysis - Version 1.58. Retrived 2014 August 27 from http://folk.

Hans De W, Ronny B, Thierry B (2013). Worked on the population genetic structure of Littorina littorea (Mollusca: Gastropoda) along a pollution gradient in the Scheldt estuary (The Netherlands) using RAPD analysis. Science of the Total Environment 325:59-69.

Hille A, Liebal K, Mosch B, Pellmann H, Schlegel M (2003). A RAPD (Random Amplified Polymorphic DNA) analysis of genetic population structure of Balea biplicata (Gastropoda: Cluasiliidae) in fragmented flood plain forests of the Elster/ Saale Riparian System. Biochemical Genetics 41(5/6):175-199.

Hufford KM, Mazer SJ (2003). Plant ecotypes: genetic differentiation in the age of ecological restoration. Trends in Ecology and Evolution 18:147-155.

Leamon AAA, Mahzabin S, Rahaman SE, Miah MF (2014). RAPD based genetic diversity of freshwater snail, Pila polita in Bangladesh. The Journal of Zoology Studies 1(5):24-29.

Liao LC, Hsiao JY (1998). Relationship between population genetic structure and riparian habitat as revealed by RAPD analysis of the rheophyte Acorus gramineus Soland (Araceae) in Taiwan. Molecular Ecology 7(10):1275-1281.

Liu B, You F, Dong B, Xiang J (2004). The comparison between allozyme and RAPD marker for the population genetic structure of Scallop Chlamys ferreri. Chinese Journal of Oceanology and Limnology 24(3):295-299.

Liu Y, Zhung W, Wan Y, Wan N (1979). Freshwater snails. In: Chinese economic mollusca. Beijing Science Publishing pp 9-20.

Madec L, Bellido A, Guiller A (2003). Shell shape of the land snail Cornu aspersum in North America: unexpected evidence of a phylogeographical splitting. Heredity 91:224231.

Madec L, Bellido A (2007). Spatial variation of shell morphometrics in the subantartic land snail Notodiscus hookeri from Crozet and Kerguelen Islands. Polar Biology 30:1571-1578.

Mead AR (1991). Anatomical criteria in the systematics of the Achatinidae (Pulmonata). Proceedings of the $10^{\text {th }}$ International Malacological Congress, Meier-Brook C (ed). Tubingen pp 549-553.

Nei M (1978). Estimation of average heterozygosity and genetic distance from a small number of individuals. Genetics 89(3):583-590.
Okon B, Ibom LA, Williams ME, Akpakpan IE (2009). Comparative evaluation of reproductive performance and some egg quality parameters of black and white skinned snails. Global Journal of Agricultural Sciences 8(1):77-80.

Okon B, Ibom LA, Udoh UH, Njume GN (2013). Phenotypic characterization of Archachatina marginata snails in Niger Delta region of Nigeria. Proceedings of the $2^{\text {nd }}$ International Conference/Workshop on Giant African Land Snail pp 2-5.

Osemeabo GJ (1992). Effects of land use and collection on the decline of African giant snails in Nigeria. Environmental Conservation (19):153-159.

Raut SK, Barker GM (2002). Achatina fulica, Bowdich and other Achatinidae as pest in Tropical Agriculture. In: Bark GM (Ed). Molluscs as crop pests. Commonwealth Agricultural Bureau International.

Reist JD (1985). An empirical evaluation of several univariate methods that adjust for size variation in morphometric data. Canadian Journal of Zoology 63:1429-1439.

Rolf J (2000). NTSYS pc Version 2.0. Exeter software, Setauket, New York.

Simpson AJG, Steindel M (1993). The use of RAPDs for the analysis of parasites. In: Pena SDJ, Chakraborty R, Epplen JT, Jeffereys J (Eds). DNA Fingerprinting: State of the sciences. Boston, Birkhauser pp 331-337.

Smith JSC, Williams JGK (1994). Arbitrary primer mediated fingerprinting in plants: Case studies in plant breeding. Taxonomy and Phylogeny pp 5-15.

Vidigal TH, Neto ED, Carvalho OS, Simpson AJ (1994). Biomphalaria glabrata: extensive genetic variation in Brazilian Isolates revealed by Random Amplified Polymorphic DNA analysis. Experimental Parasitology 79:187-194. 